\title{
Investigation of urinary abnormalities and risk factors for kidney disease in the World Kidney Day campaigns in Northeast Brazil
}

\author{
Sônia M.H.A. Araújo ${ }^{1}$, Maria Zenaide D. Ribeiro ${ }^{2}$, Rafael S. A. Lima², Geraldo B. Silva Junior ${ }^{1 *}$, Camilla N. Jacinto ${ }^{2}$, \\ Moises Francisco da Cruz Neto², Valdenor N. Feitosa Junior², Maríla M. V. Girão², Elizabeth F. Daher² \\ ${ }^{1}$ School of Medicine, Post-Graduation Program in Collective Health, Health Sciences Center, University of Fortaleza. Fortaleza, Ceará, Brazil \\ 2Post-Graduation Program in Medical Sciences, Department of Internal Medicine, School of Medicine, Federal University of Ceará. Fortaleza, Ceará, Brazil
}

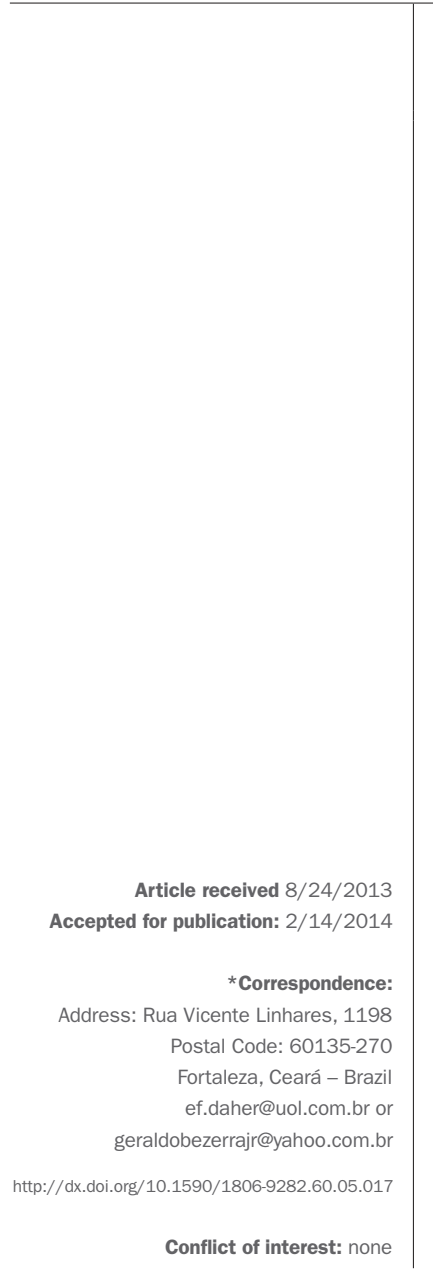

\section{SUMmARY}

Objective: chronic kidney disease (CKD) is an increasing common problem in the world due to the exponential growth of diabetes mellitus, hypertension and other risk factors. The aim of this study is to investigate urinary abnormalities and risk factors for kidney disease in the general population.

Methods: this study was performed from data collected during the annual World Kidney Day (WKD) campaigns, in Fortaleza, Ceará, Brazil, between 2009 and 2012. The population sought assistance spontaneously in stands placed in high people-traffic areas.

Results: among 2,637 individuals interviewed, the mean age was $50.7 \pm 15.7$ years and $53 \%$ were male. The main risk factors found were sedentarism $(60.7 \%)$, obesity (22.7\%) and smoking (19.8\%). Blood pressure (BP) $\geq 140 \times 90 \mathrm{mmHg}$ was found in 877 (33\%). Increased BP was found for the first time in 527 cases $(19.9 \%)$. Cardiovascular diseases were reported in 228 (8.6\%). Diabetes was related by 343 (13\%). Capillary blood glucose $\geq 200 \mathrm{mg} / \mathrm{dL}$ was found in $127(4.8 \%)$ and it was $\geq 200 \mathrm{mg} / \mathrm{dL}$ for the first time in $30(1.13 \%)$. Urinalysis was performed in 1,151 people and found proteinuria in $269(23.3 \%)$. Proteinuria was most frequent in hypertension people $(77.3 \%$ vs. $55.8 \%$, $\mathrm{p}=0.0001)$, diabetes mellitus $(22.7 \%$ vs. $15.2 \%$, $\mathrm{p}=0.005)$ and elderly ( $42.1 \%$ vs. $30.7 \%, \mathrm{p}=0.0007)$.

Conclusion: risk factors for CKD are frequent in the general population. Many individuals had hypertension and diabetes and did not know this. It is important to regularly perform actions like WKD in order to early detect potential candidates for CKD.

Keywords: world kidney day, urinary abnormalities, chronic kidney disease, hypertension, diabetes mellitus.

\section{INTRODUCTION}

Chronic kidney disease (CKD) is an increasing common problem in the world. CKD is now a global public health problem due to the exponential growth of diabetes mellitus, hypertension and other risk factors. ${ }^{1}$ By 2030 , the number of people undergoing kidney replacement therapy in the United States is expected to increase to more than 2 million. ${ }^{1}$

Early detection of kidney disease offers the potential to improve outcomes by allowing for more time to intervene when most patients are still asymptomatic. ${ }^{2}$ Abnor- mal results identified during screening tests are not considered diagnostic but rather indicative of increased risk. There are few studies investigating renal dysfunction in the general population in Brazil. In a previous study conducted in the State of Minas Gerais, the prevalence of elevated creatinine was higher in the elderly. ${ }^{3}$ In another study investigating the prevalence of CKD (stages 3, 4 and 5) in adults was $9.6 \%{ }^{4}$

End-stage renal disease (ESRD) has reached epidemic proportion with more than 400,000 affected individuals 
in the United States and over one million worldwide. ${ }^{5}$ This staggering number represents only the tip of the iceberg, as the incidence of chronic kidney disease (CKD) is at least 30-fold higher than that of ESRD. ${ }^{6}$

The CARE project identified $56 \%$ of 348 individuals as at risk of diabetes, hypertension, and/or kidney disease and supported the feasibility of a regional targeted kidney disease screening action to identify individuals at risk. ${ }^{7}$

The aim of this study is to investigate urinary abnormalities and risk factors for kidney disease in the general population.

\section{Methods}

This study was performed from data collected during the annual World Kidney Day campaigns in Fortaleza, Ceará, Brazil, on $11^{\text {th }}$ March 2009, $10^{\text {th }}$ March 2010, $10^{\text {th }}$ March 2011 and $8^{\text {th }}$ March 2012. During the events, stands were placed in high people-traffic areas in which the population sought assistance spontaneously. The protocol of this study was approved by the ethics committee of the Federal University of Ceará, Brazil. A signed consent was obtained before filling out the forms.

The following data were collected: age, gender, weight, height and cardiovascular risk factors (smoking, physical inactivity, obesity and family history). Body mass in$\operatorname{dex}(\mathrm{BMI})$ was calculated using weight and height, and obesity was considered as BMI $\geq 30 \mathrm{~kg} / \mathrm{m}^{2}$. Physical inactivity was considered when the individual reported expending less than $10 \%$ of their daily energy in the performance of moderate- and high-intensity activities. ${ }^{8}$

The following services were offered: guidelines for a healthy lifestyle, blood pressure and capillary blood glucose (with the equipment One touch ultra - Johnson \& Johnson) measurement and urinalysis (dipstick Neocheck - Neomedica). Urinalysis was offered for each interviewed individual and it was performed for those who accepted to collect a urine sample.

Blood pressure was measured according to standard methods with free-mercury aneroid equipment (Welch Allyn - Tycos ${ }^{\circledR}$ ). Patients were calmly seated in a chair for at least 5 minutes before their blood pressure was measured, their feet were placed on the floor and the arm where blood pressure would be measured was at the height of the heart. Patients had not drunk any coffee and had not smoked or made physical exercise 30 minutes before blood pressure was measured. A cuff of appropriate size was used. Two blood pressure measurements were done in the right arm, with 5 minutes interval, and the average was calculated. ${ }^{9}$ The tests were performed by medical stu- dents and professors of the Federal University of Ceará. Patients identified as having hypertension and/or diabetes were referred to the outpatients' clinics of the Walter Cantídio University Hospital.

Statistical analysis was performed using Epi-Info, version $6.04 \mathrm{~b}$. The results were expressed by means \pm standard deviation or relative frequencies. Comparison of parameters for two groups was done by means of Student's $t$ test and Fisher's exact test. A comparison between patients with and without proteinuria was done. Descriptive values below $5 \%(p<0.05)$ were considered statistically significant.

\section{Results}

A total of 2,637 individuals were interviewed. The mean age was $50.7 \pm 15.7$ years and $53 \%$ were male. The main cardiovascular risk factors found were sedentary lifestyle (60.7\%), obesity (22.7\%) and smoking (19.8\%). Previous diagnosis of hypertension was related by 906 (34.3\%) individuals. Blood pressure higher than $140 / 90 \mathrm{mmHg}$ was found in 877 (33\%) participants. First finding of increased blood pressure was found in 527 (19.9\%). Cardiovascular diseases were reported in 228 (8.6\%). Diabetes was related by 343 (13\%) individuals. Capillary blood glucose higher than $200 \mathrm{mg} / \mathrm{dL}$ was found in 127 (4.8\%) and it was higher than $200 \mathrm{mg} / \mathrm{dL}$ for the first time in 30 cases $(1.13 \%)$. The majority of the interviewed (38.6\%) presented capillary blood glucose between 100 and $126 \mathrm{mg} / \mathrm{dL}$. Urinalysis was performed in 1,151 patients and found proteinuria in 269 cases (23.3\%). Proteinuria was most frequent in patients with hypertension $(77.3 \%$ vs. $55.8 \%$, $\mathrm{p}=0.0001)$, diabetes mellitus ( $22.7 \%$ vs. $15.2 \%, \mathrm{p}=0.005)$ and elderly individuals ( $42.1 \%$ vs. $30.7 \%, \mathrm{p}=0.0007$ ).

\section{Discussion}

There are few studies investigating the prevalence of CKD in the general population. Our study tried to identify risk factors for renal dysfunction in the general population in a metropolitan area in Brazil, mainly hypertension, diabetes mellitus and proteinuria. The National Kidney Foundation's Kidney Early Evaluation Program (NKF KEEP) identifies individuals at increased CKD risk by using inclusion and exclusion criteria. ${ }^{10}$ People are included if they have at least one of the following criteria: hypertension, diabetes and family history of hypertension, diabetes and chronic kidney disease. Individuals undergoing renal replacement therapy or kidney transplantation were excluded. The overall CKD prevalence found was $29 \%$ and only $7 \%$ self-reported CKD, demonstrating low CKD awareness in general population. ${ }^{10}$ 
In the present study with 2,637 individuals, the mean age was 51 years and $53 \%$ were male. NKF KEEP included 61,675 participants with 54 years and $68 \%$ were female. ${ }^{10}$ KEEP Japan included 1,065 participants with 60 years old and 53\% were female. ${ }^{11}$ In KEEP Mexico, 1,519 individuals participated and more than $70 \%$ were female. ${ }^{12}$

High blood pressure was found in 33\% of measurements and first finding of increased blood pressure was found in $20 \%$ of subjects in our study, which means that an important proportion of patients had hypertension and did not know it. Among NKF KEEP participants, $66 \%$ have increased blood pressure, $17 \%$ have isolated measured hypertension and $53 \%$ have self-reported hypertension. ${ }^{10}$ Hypertension was self-reported in $59 \%{ }^{10,11}$ and in $62 \%$ in KEEP Mexico. ${ }^{12}$

In our cohort, diabetes was related by $13 \%$. Capillary blood glucose higher than $200 \mathrm{mg} / \mathrm{dL}$ was found in $5 \%$ and it was higher than $200 \mathrm{mg} / \mathrm{dL}$ for the first time in $1 \%$, which can be considered as diagnosis of diabetes. NKF KEEP data found that $30 \%$ of participants have diabetes, self-reported $(25 \%)$ or based on glucose testing alone $(5 \%)^{10}$. Fifty percent of NKF KEEP participants who selfreported diabetes have a high measured glucose level. In KEEP Japan, 27\% self-reported diabetes. Glycemic control was higher than $139 \mathrm{mg} / \mathrm{dL}$ for $35 \%$ of diabetic participants. High blood glucose was newly found in 21 participants. ${ }^{11}$

Among all participants, $20.8 \%$ in KEEP Japan and $21.2 \%$ in NKF KEEP self-reported one or more cardiovascular diseases. ${ }^{10,11}$ In the present study, these conditions were reported in $9 \%$ of individuals.

Urine protein, determined by the dipstick method, was positive for $7.2 \%$ in KEEP Japan. ${ }^{11}$ Abreu et al. ${ }^{13}$ found $26 \%$ of hematuria e $5 \%$ of proteinuria among 200 elderly subjects in São Paulo, Brazil. Different from others reports, in the present study, urinalysis was performed in 1,151 individuals and found a high level of proteinuria (23.3\%).

This study has some limitations. The findings may not be generalizable to the total Brazilian population as the study includes only self-referred population. We could not estimate glomerular rate filtration because there was no measurement of serum creatinine. A single measurement of blood pressure in health campaigns does not allow diagnosing hypertension nor preclude the possibility of white-coat effect.

Lack of health insurance is an independent risk factor for early death and ESRD in individuals with high risk of kidney disease. ${ }^{14}$ The goals of early CKD detection are to prevent CKD progression and associated compli- cations, thus improving patient outcomes. Campaigns are important to warn people who may be at risk of developing hypertension and for those who already have hypertension and had not yet been diagnosed.

In summary, risk factors for CKD are frequent in the general population. Many individuals had hypertension and diabetes and did not know it. It is important to regularly perform actions like WKD in order to early detect potential candidates for CKD. Campaigns like World Kidney Day have a good cost-effectiveness ratio because in the absence of more elaborated studies to evaluate the prevalence of CKD they act as an alert to the population of the risk of hypertension and diabetes, mainly in people with family history, overweight, obesity, sedentarism and other risk factors for renocardiovascular diseases. Studies like this are important to early detect risk factors for renal function loss and to adopt measures to slow the progression of kidney disease. These measures can impact public health since fewer patients would need renal replacement therapy if kidney disease is detected in early stages.

TABLE 1 Epidemiological characteristics and risk factors for chronic kidney disease in 2,637 individuals in Northeast Brazil

\begin{tabular}{|c|c|c|}
\hline & $\mathbf{N}$ & $\%$ \\
\hline \multicolumn{3}{|l|}{ Age, years } \\
\hline $18-30$ & 312 & 11.8 \\
\hline $31-45$ & 674 & 25.5 \\
\hline $46-60$ & 891 & 33.7 \\
\hline $61-75$ & 618 & 23.4 \\
\hline$>75$ & 142 & 5.3 \\
\hline \multicolumn{3}{|l|}{ Gender } \\
\hline Male & 1235 & 47 \\
\hline Female & 1402 & 53 \\
\hline \multicolumn{3}{|l|}{ Risk factors } \\
\hline Smoking & 523 & 19.8 \\
\hline Physical inactivity & 1601 & 60.7 \\
\hline Obesity & 599 & 22.7 \\
\hline Cardiovascular diseases & 228 & 8.6 \\
\hline Proteinuria & 269 & 23.3 \\
\hline
\end{tabular}

TABLE 2 Urinary findings in 1,151 in participants Northeast of Brazil

\begin{tabular}{l|l|l} 
& N & $\%$ \\
\hline Proteinuria & 269 & 23.3 \\
\hline Leukocyturia & 144 & 12.5 \\
\hline Hematuria & 38 & 3.3 \\
\hline
\end{tabular}


TABLE 3 Comparison of individuals with and without proteinuria among 1,151 participants in Northeast Brazil

\begin{tabular}{|c|c|c|c|}
\hline & $\begin{array}{l}\text { With proteinuria } \\
(n=269)\end{array}$ & $\begin{array}{l}\text { Without proteinuria } \\
(n=882)\end{array}$ & $\mathbf{P}$ \\
\hline Age, years & $54.3 \pm 15.8$ & $51.4 \pm 14.5$ & 0.005 \\
\hline \multicolumn{4}{|l|}{ Gender } \\
\hline Male (\%) & $117(43.5)$ & $393(44.6)$ & \\
\hline Female (\%) & $152(56.5)$ & $489(55.4)$ & 0.77 \\
\hline Smoking (\%) & $64(23.7)$ & $204(23.1)$ & 0.86 \\
\hline Obesity (\%) & $80(29.7)$ & $234(26.5)$ & 0.30 \\
\hline Sedentarism (\%) & $172(63.9)$ & $556(63)$ & 0.82 \\
\hline Diabetes mellitus (\%) & $56(20.8)$ & $120(13.6)$ & 0.005 \\
\hline $\mathrm{CBG} \geq 200 \mathrm{mg} / \mathrm{dL}(\%)$ & $5(1.8)$ & $14(1.5)$ & 0.78 \\
\hline Hypertension (\%) & $155(57.6)$ & $318(36)$ & 0.0001 \\
\hline $\mathrm{BP} \geq 140 \times 90 \mathrm{mmHg}$ & $53(19.7)$ & $175(19.8)$ & 1.0 \\
\hline $\mathrm{SBP}(\mathrm{mmHg})$ & $138 \pm 22$ & $129 \pm 19$ & 0.0001 \\
\hline $\mathrm{DBP}(\mathrm{mmHg})$ & $85 \pm 12$ & $82 \pm 11$ & 0.0001 \\
\hline Cardiovascular diseases (\%) & $33(12.2)$ & $34(3.8)$ & 0.0001 \\
\hline Renal diseases family history (\%) & $44(16.3)$ & $71(8.0)$ & 0.0002 \\
\hline $\mathrm{BMI}\left(\mathrm{kg} / \mathrm{m}^{2}\right)$ & $28.1 \pm 4.8$ & $27.5 \pm 4.5$ & 0.05 \\
\hline
\end{tabular}

$\mathrm{CBG}=$ Capillary blood glucose, $\mathrm{BP}=$ blood pressure, $\mathrm{SBP}=$ systolic blood pressure, $\mathrm{DBP}=$ diastolic blood pressure, $\mathrm{BMI}=$ body mass index . Values expressed as mean $\pm \mathrm{SD}$. Significant $\mathrm{P}<0.05$.

\section{Resumo}

Investigação de alterações urinárias e fatores de risco para doença renal nas campanhas do Dia Mundial do Rim no Nordeste do Brasil.

Objetivo: a doença renal crônica (DRC) é um problema crescente no mundo em razão do crescimento exponencial do diabetes mellitus, da hipertensão e de outros fatores de risco. O objetivo deste estudo é investigar alterações urinárias e fatores de risco para doença renal na população geral.

Métodos: este estudo foi realizado a partir de dados coletados durante as campanhas anuais do Dia Mundial do Rim, em Fortaleza, Ceará, Brasil, entre 2009 e 2012. A população buscou atendimento espontaneamente nos stands montados em locais de alto tráfego de pessoas.

Resultados: entre 2.637 indivíduos entrevistados, a média de idade foi de $50,7 \pm 15,7$ anos, sendo $53 \%$ do gênero masculino. Os principais fatores de risco encontrados foram sedentarismo $(60,7 \%)$, obesidade $(22,7 \%)$ e tabagismo (19,8\%). Pressão arterial (PA) $\geq 140 \times 90 \mathrm{mmHg}$ foi encontrada em 877 casos (33\%). Aumento da PA foi encontrado pela primeira vez em 527 casos (19,9\%). Doenças cardiovasculares foram relatadas por 228 indivíduos (8,6\%). Diabetes foi relatado por 343 indivíduos (13\%). Glicemia capilar $\geq 200 \mathrm{mg} / \mathrm{dL}$ foi encontrada em $127 \mathrm{ca}-$ sos $(4,8 \%)$ e $\geq 200 \mathrm{mg} / \mathrm{dL}$ pela primeira vez em $30(1,13 \%)$. O exame de urina foi realizado por 1.151 pessoas, sendo encontrada proteinúria em 269 casos (23,3\%). Proteinúria foi mais frequente em pessoas com hipertensão (77,3\% vs. $55,8 \%, \mathrm{p}=0,0001)$, diabetes mellitus $(22,7 \%$ vs. $15,2 \%$, $\mathrm{p}=0,005)$ e em idosos $(42,1 \%$ vs. $30,7 \%, \mathrm{p}=0,0007)$.

Conclusão: fatores de risco para DRC são frequentes na população geral. Muitos indivíduos tinham hipertensão e diabetes e não sabiam disso. É importante a realização de ações como o Dia Mundial do Rim com o objetivo de detectar precocemente potenciais candidatos à DRC.

Palavras-chave: Dia Mundial do Rim; alterações urinárias; doença renal crônica; hipertensão; diabetes mellitus.

\section{References}

1. Gilbertson DT, Liu J, Xue JL, Louis TA, Solid CA, Ebben JP, et al. Projecting the number of patients with end-stage renal disease in the United States to the year 2015. J Am Soc Nephrol. 2005;16:3736-41.

2. Vassalotti JA, Li S, Chen SC, Collins AJ. Screening populations at increased risk of CKD: the Kidney Early Evaluation Program (KEEP) and the public health problem. Am J Kidney Dis. 2009;53(3 Suppl 3):S107-S14.

3. Passos VMA, Barreto SM, Lima-Costa MFF, The Bambuí Health and Ageing Study (BHAS) Group. Detection of renal dysfunction based on serum creatinine levels in a Brazilian community. The Bambuí Health and Ageing Study. Braz J Med Biol Res. 2003;36:393-401.

4. Bastos RMR, Bastos MG, Ribeiro LC, Bastos RV, Teixeira MTB. Prevalência da doença renal crônica nos estágios 3, 4 e 5 em adultos. Rev Assoc Med Bras. 2009;55:40-4. 
5. Satko SG, Freedman BI, Moossavi S. Genetic factors in end-stage renal disease. Kidney Int Suppl. 2005;(94):S46-S9.

6. Jones CA, McQuillan GM, Kusek JW, Eberhardt MS, Herman WH, Coresh $\mathrm{J}$, et al. Serum creatinine levels in the US population: third National Health and Nutrition Examination Survey. Am J Kidney Dis. 1998;32:992-9.

7. Brown WW, Collins A, Chen SC, King K, Molony D, Gannon MR, et al. Identification of persons at high risk for kidney disease via targeted screening: The NKF Kidney Early Evaluation Program. Kidney Int Suppl. 2003;(83):S50-S5.

8. Bernstein MS, Morabia A, Sloutskis D. Definition and prevalence of sedentarims in an urban population. Am J Public Health. 1999;89:862-7.

9. Chobanian A, Bakris G, Black HR, Cushman WC, Green LA, Izzo JL Jr, et al. Seventh report of the Joint National Committee on Prevention, Detection, Evaluation and Treatment of High Blood Pressure. Hypertension. 2003;42:1206-52
10. National Kidney Foundation: KEEP Kidney Early Evaluation Program Annual Data Report 2006. Am J Kidney Dis. 2007;49(1 Suppl 1):S1-S160.

11. Takahashi S, Okada K, Yanai M. The Kidney Early Evaluation Program (KEEP) of Japan: results from the initial screening period. Kidney Int Suppl. 2010;(116):S17-S23.

12. Obrador GT, García-García G, Villa AR, Rubilar X, Olvera N, Ferreira E, et al. Prevalence of chronic kidney disease in the Kidney Early Evaluation Program (KEEP) México and comparison with KEEP US. Kidney Int Suppl. 2010;(116): S2-S8.

13. Abreu PF, Ramos LR, Sesso R. Abnormalities of renal function in the elderly. Geriatr Nephrol Urol. 1999;9:141-5.

14. Jurkovitz CT, Li S, Norris KC, Saab G, Bomback AS, Whaley-Connell AT, McCullough PA; KEEP Investigators. Association between lack of health insurance and risk of death and ESRD: results from the Kidney Early Evaluation Program (KEEP). Am J Kidney Dis. 2013;61(4 Suppl 2):S24-S32. 